\title{
Development and validation of the Purity Orientation-Pollution
}

\section{Avoidance Scale: A study with Japanese sample}

Hideya KITAMURA $^{\mathrm{a} *}$ and Akiko MATSUO ${ }^{\mathrm{b}}$ (ORCiD ID: 0000-0002-6293-5501)

${ }^{a}$ Department of Social Psychology, Toyo University, Tokyo, Japan; ${ }^{b}$ Department of Psychology, Tokaigakuen University, Nagoya, Japan

*Corresponding author: Hideya Kitamura, Department of Social Psychology, Toyo

University, 5-28-20 Hakusan, Bunkyo, Tokyo 112-8606, Japan.

kitamura@toyo.jp +81-3-3945-7482

\begin{abstract}
The Moral Foundations Theory (MFT) proposes that there are five moral foundations that work as the standard to make moral judgements. Among them, Purity foundation is a complex concept. It is considered to be a distinctive foundation compared to the other ones partly because it involves religious beliefs. The assumption underlying Purity foundation is Christian beliefs so that the MFT was developed and made prevalent mostly in the Western cultures. However, because of that assumption, cultural differences in perceiving Purity foundation should be observed with a non-Western sample, such as Japan. It would be important to discuss and clarify Japanese unique aspect of their orientation toward the pure and impure. We constituted a scale to measure people's tendency towards Purity Orientation-Pollution Avoidance (POPA), based on the purity/sanctity subscale of the Moral Foundations Theory. For validation, we administered several scales along with POPA. In study 1, we developed the scale and measured the relationship between the degree of one's POPA, disgust, and animism. We identified four factors as POPA subscales. In study 2, we investigated the test-retest reliability of POPA and conducted questionnaire surveys to measure attitudes toward paranormal phenomena and the degree of concern for each of the moral foundations. The results showed the validity of the scale, based on the moderate correlations with other scales. The POPA can be a promising tool to better understand the phenomena involving purity foundation in the Japanese context.
\end{abstract}

Keywords: Moral Foundations Theory, morality, Japan, purity, culture 


\section{Introduction}

Research on morality has been increasing significantly, with such studies gaining significance in a conflict-ridden world, given the growing disputes between and within countries and even districts. In recent times, the literature on the standard of moral judgment has been accumulated since the intuitionist model of moral judgment argues that people's feelings of wrongness come first and the rationale for the judgment follows. According to certain proposed theories about moral standards, people have a fixed number of modes of reasoning about moral judgment, which is called moral pluralism. These multiple ethics guide moral judgment by providing a template for understanding and interpreting potentially moral-relevant behaviour. As a result, people reach conclusions about the rightness or wrongness of a specific behaviour by evaluating it with respect to one of the ethics.

Shweder et al. (1997) highlighted three important components to provide a reason for a moral-relevant situation by investigating the moral standards in Western and Eastern cultures. Based on the idea of moral pluralism, they advocated autonomy, community and divine ethics in moral judgment. The authors argued that community and divinity have an especially significant status in Eastern cultures. Divinity provides an important value for religious purity. Graham, Haidt, Koleva, Motyl, Iyer, Wojcik and Ditto (2013) advocated a theory called Moral Foundations Theory (MFT), which states that people utilise the domains of care, fairness, group, authority and purity to make moral judgments. As a theory that was extended from Shweder's three ethics, MFT identifies care and fairness moral foundations as the components of the autonomy ethic pertaining to individual rights and justice. Ingroup and authority moral foundations are the components of the community ethics, which are sensitive to one's membership of groups with hierarchy. Divinity ethic is essentially equivalent to the purity foundation. 
By applying one of these three ethics to potentially moral violating situations, people recognise whether those situations are right or wrong, and understand why they are so.

While Haidt (2012) considered moral foundations as Shweder's three major components by connecting care and fairness, and loyalty and authority, the authors perceive purity as an independent factor in moral judgment. Kaur and Sasahara (2016) effectively analysed tweets using latent semantic analysis and found that purity is a unique component independent of the other foundations. Purity foundation is reported to be relevant to disgust, which serves to avoid danger from food poisoning and subsequently preventing illness (van Leeuwen et al., 2012; Rozin, 1999). Therefore, it is reasonable to state that moral purity is also relevant to purity of the body or cleanliness (Zhong \& Liljenquist, 2006). Beyond physical cleanliness, purity is related to religiosity (Graham \& Haidt, 2010; Preston \& Ritter, 2012). In addition, purity involves sexuality or sexual behaviour. In the olden days, people considered sexual behaviour as offensive, and were not willing to discuss topics concerning sex, especially in public, because it was considered a taboo. Douglas (2003), an anthropologist, reviewed the idea of impurity (i.e., the opposite idea of purity) and argued that the impure consisted of the representations of death, blood, sexuality, and body.

Based on Douglas' claim (2003), purity can further involve respect for the substantially invisible, such as sanctity, that does not necessarily rely on a clear ground for their existence. Respect for the invisible has been eagerly investigated in the recent literature on awe. Awe is defined as an emotional response to vast perceptual stimuli that updates one's cognitive framework (Keltner \& Haidt, 2003). Awe is often induced by pictures or videos depicting magnificent landscapes (e.g., mountains, universe) (Shiota, Keltner, \& Mossman, 2007). Through the experience of being in awe of nature, the psychological state of purity could be accomplished among Japanese people 
(Ishikawa, 2012). This psychological purity is regarded as a feeling of cleanness and rejuvenation, which is theoretically in accordance with the value of purity.

Purity has not yet been well defined because cultural differences can exist in the context of purity. Specifically, the representations of purity can vary depending on culture, which is the reason why researchers find it difficult to measure purity. Christianity, which is a popular religion in the West, is not so prevalent in Asian cultures. Asian countries, such as Japan, often follow the culture of Buddhism or polytheism, or a mixture of both. As mentioned above, purity as a virtue has a central idea of sacredness, but sanctity represented in theoretical purity may be limited to Christianity. Conversely, the violation of purity or impurity is considered to be associated with infection and sexual components (Koleva, Graham, Iyer, Ditto, \& Haidt, 2012; van Leeuwen et al., 2012). However, these concepts have not been tested in relation to the purity foundation in Asian cultures. As a result, the purity items on the questionnaires that measure one's importance of moral foundations may not be directly applied to Asian participants (Iurino \& Saucier, 2018). The investigation of the culturally specific purity foundation would be beneficial. Because variations in results from research on social psychology theories have been observed even inside the "Asian groups" (e.g., East Asians vs. South Asians; Gelfand \& Danison, 2020), cultural differences in the perception of purity would be present across Asian cultures. Thus, we specifically look into the purity foundation in Japan in the current research because the sense of purity is not systematically organized or investigated in the field of psychology in Japanese culture.

Impurity (Kegare in Japanese) and people's tendency to avoid impurity, rather than purity itself, has been historically discussed in diverse fields in Japan (e.g., religion, anthropology) and interwoven in various contexts (e.g., cultural, historical) 
(e.g., Miyamoto, 2008; Namihira, 2009). In Japan, impurity is a phenomenon that includes double aspects, one of which comes from Shintoism and Buddhism and the other is a theoretical framework used in academic fields. The former aspect is similar to Douglas' claim about (im)purity, arguing that the nature of impurity is disorder and that impurity is a matter about something out of place (Miyamoto, 2008). While Douglas (2003) based her theoretical construction mainly on Judaism, Japanese impurity in this sense derives from Shintoism and Buddhism (often in a mixed form). Natural disasters, death, and blood (and anything that symbolizes them) is viewed as impurity. Impurity is infectious and can be removed through appropriate rituals and passage of time (Ito, 2002).

As mentioned above, religion is an essential element of purity. Japanese people do not affiliate themselves with a religion, but they are not non-religious. The characteristics of religion for the Japanese is different from the West to a large degree. Aithough Japanese people do not have specific religious dogmas or groups, they do have something to believe in from ancient times. That target can be understood as nature worship, but it is a naive feeling since ancient times and concerns animism. Of course, there is no such religion as an animism sect, thereby the naive feeling is not organized as a religious community or clarified through scriptures. Thus, believers themselves are not likely to be sure of their own dogmas and disciplines inside them.

However, some traditional institutions, such as shrines symbolized by Shintoism and temples symbolized by Buddhism, are somewhat rooted in Japanese people's minds, and embody their religious spirits deep inside. Because most Japanese people do not consciously believe in a specific religion with its clear dogmas, they cannot even discriminate Shintoism from Buddhism. As a result, they mix up Shintoism and 
Buddhism, but the fact of their mixing itself is part of Japanese tradition since 1000 years ago $(\mathrm{O}, 2009)$.

Douglas' theory is criticized for her full application of purity as the Jewish symbolization to people's real life (Miyamoto, 2008), but Japanese researchers (albeit outside psychology) have attempt to sophisticate the religious meaning of impurity to use as a framework explaining practical situations in everyday life in Japan (the latter aspect of Japanese purity described above). In addition to the religion-oriented sense of impurity, social sense of impurity in Japan includes something out of order and the process surrounding it -- moving from one place to another over its boundary (e.g., Saliva in one's mouth is not impure because it is inside its appropriate place. However, once s/he lets that saliva out of the mouth, the saliva itself and the process to let it out become impure) (Baba, 2000; Usui, 1986). One important point about impurity in Japan is that even "pure" targets can be degraded when they are moved from their original place (i.e., the behavior to take a pebble from the territory of a shrine and the pebble itself after the behavior are both impure). Thus, avoidance of such impurity has social meaning in these days (Tanaka, 2004). Further, because impurity is believed to be removed through rituals to obtain the status of purity, purity is often associated with something "good" and impurity is with "bad" (Baba, 2000; Xu, 2013). That can be why (im)purity became a part of morality, at least in Japan. However, those arguments have been not of interest in psychology.

In sum, previous research conducted in the West has found that the concept of purity is symbolically associated with religiosity, physical cleanliness, sexual behaviour and illness. We developed a purity scale that can be applied to Japanese people by referring to the Moral Foundations Questionnaire (MFQ) as an existing framework, which measures moral foundation from the Western perspective. The theoretically 
opposite concept of purity can be defined as pollution. Pollution is an attitude that is wary of and avoids contamination, dirt and infection. The scale we developed features the core items involving animism and respect for shrines/ temples, along with the other items about taboos of body and sexual matters and threats of diseases and impurity caused by infection. To test the validity of our purity scale for Japanese people, we measured one's level of animism (one's belief that natural objects possess minds and spirits and one's worship of nature involving awe), one's familiarity with and the tendency to believe in non-scientific supernatural phenomena, and the emotion of disgust that has been found to be associated with pollution. We report here how we developed our purity scale among the Japanese (the Purity Orientation-Pollution Avoidance; POPA) and tested its validity and reliability.

\section{Study 1}

The POPA was developed, and we identified the items, confirmed the factors and validated it using the Japanese version of the Disgust Scale-Revised (DS-R-J) (Iwasa, Tanaka, \& Yamada, 2018) and Animism Scales (Ikeuchi, 2010). The POPA should be relevant to disgust and Haidt's moral foundations. Disgust is found to be relevant to religiosity, personal hygiene and illness. Since we needed to find the difference between the concepts of disgust and avoidance of pollution (i.e., impurity), the DS-R-J and Animism Scales were included to investigate the validity of our POPA. It was predicted that participants with a high score of purity orientation would have high scores of disgust sensitivity and animism-orientation. However, because one's purity orientation involves the feeling of psychological pollution that is different from physical pollution, the correlation between the POPA and disgust sensitivity would be not very high, but moderate. Likewise, animism involves the idea that one views an inanimate object as 
the other self of his/herself, which is different from one's purity orientation. Thus, the correlation between the POPA and animism would be moderate, as well.

\section{Method}

\section{Participants}

Participants included 411 Japanese undergraduates enrolled in introductory psychology classes at a major Japanese private university, of whom 229 were males. They agreed to participate in the study for extra credit or credit towards a course research requirement. There was no financial incentive provided to the participants. The survey was delivered online with Google Forms. Ethical review and approval by the ethics committee of Toyo University (P18033) were obtained before conducting this study. The mean age of the participants was $19.50(S D=1.40)$.

\section{Measures}

$P O P A$

A sample of undergraduate students from Japan $(n=63)$ freely generated situations in line with each of Shweder's three ethics, as part of a different cross-cultural project. In this process of situation collection, the definitions of the three ethics were first explained to the participants, and they were asked to describe as many moral violation situations as possible that they had experienced, heard, or imagined for each domain. All sessions were conducted in a small-group setting that consists of 1-3 participants in the same room for 20 minutes (cf. Morling, Uchida, \& Frentrup, 2015).

These definitions were developed by the second author, based on the works of Shweder and Haidt (Shweder et al., 1997; Haidt, 2012). After creating the first draft, she discussed whether the descriptions are appropriate in accuracy and length with two researchers specializing in morality research. Because the descriptions were needed to be reasonably easy to understand and imagine to lay people, the second author then 
revised the original drafts based on feedback received from two undergraduate students. The final version of descriptions presented to the participants were as follows:

Ethic of Autonomy: This perspective is based on the idea that people are, first and foremost, autonomous individuals with wants, needs, and preferences. People should not prevent each other from satisfying these wants, needs, and preferences as they see fit. When people do not interfere too much in each other's projects and respect each other's opinions and choices, societies develop moral concepts such as rights, liberty, and justice.

Ethic of Community: This perspective is based on the idea that people are, first and foremost, members of communities such as families, teams, armies, companies, tribes, and nations. People should not disturb the social order. When each individual fulfills the role/duty assigned to him/her, societies develop moral concepts such as duty, hierarchy, tradition, respect, and reputation.

Ethic of Divinity: This perspective is based on the idea that people, first and foremost, exist with the spiritual realm and are connected to the divine soul beyond our secular world. People should therefore not degrade or dishonor their own spirit, that of others, or the sanctity of the natural order of things. Even when one is fulfilling his/her role /duty to his/her community, s/he is not allowed to behave in a disgusting way. When people protect themselves and others from degradation, societies develop moral concepts such as sanctity, elevation, and purity.

Based on the 257 descriptions of divinity violations collected, we prepared the items mainly relevant to (1) religiosity, (2) death, (3) nature worship, (4) body, (5) 
sexual issues and (6) disgust of cleanliness and uncleanness. Those items include such Japanese unique customs as seasonal grave visiting. Some examples included 'to scribble on the shrine wall' and 'to insult the dead.' We considered that the purity foundation among the Japanese includes psychological purity as an important factor in addition to physical purity (i.e., cleanliness) because the Japanese would think that it must be a way of attaining purity in their mental state. For example, many Japanese believe that standing under a waterfall at the river in the mountain is a powerful and effective way of attaining purity (cf. Uehara, 2017, for Japanese people's cleanliness). Overall, 48 items were prepared to measure purity orientation and the likelihood to avoid pollution. Each item was rated on a Likert-type scale, ranging from 1 (not at all/almost never) to 7 (very much/almost always) (The materials, including the whole questionnaire, are available online at https://osf.io/keuwd/?view_only=8a2c8a7280a04e149e8e3966a0f9820d).

\section{Disgust}

The DS-R-J (Iwasa et al., 2018) Scale measures the degree of an individual's reaction to disgust elicitors with 18 items. The disgust elicitors are categorised into three subscales: core disgust (CD; 8 items), animal reminder disgust (AR; 5 items) and contamination disgust (CO; 5 items). The DS-R-J Scale was found to have a sufficient level of reliability and validity with a Japanese sample. Some sample items include 'It would not upset me at all to watch a person with a glass eye take it out of the socket' and 'You are about to drink a glass of milk when you smell that it is spoiled.'

\section{Animism}

The Animism Scale (Ikeuchi, 2010) is a self-report measure to quantify one's animism, which is defined as "the phenomenon that people perceive the existence of life and/or God in inanimate objects, even though they know that these objects are not actually 
alive." This scale has 14 items and it was found to comprise three factors. Some sample items include 'I sometimes give names to the objects around me' and 'I believe in multiple gods, such as the god of mountains and another god of the ocean.'

\section{Procedure}

The participants were informed of the link to the above questionnaires during the class where they were offered the opportunity to earn extra credit points for their participation. They anonymously responded to the three scales, POPA, DS-R-J and Animism online outside the class. We administered another scale, but it was not relevant to this study. The order of the questionnaires was counterbalanced.

\section{Results}

Examining the scree plot, we performed an exploratory factor analysis for POPA and obtained loadings using the principal factor method with oblimin rotation. Twenty-one items were excluded because of low factor loadings for all four factors $(<0.40)$, and each of their loadings did not belong to one factor. We then conducted a revised exploratory factor analysis. As a result, the original 48 items were reduced to 27 items. Four factors were found, as shown in Table 1. 
Table 1.

Revised exploratory factor analysis of the POPA items $(N=411)$.

\begin{tabular}{|c|c|c|c|c|c|c|}
\hline item & Wording & $\mathrm{F} 1$ & $\mathrm{~F} 2$ & F3 & F4 & $h^{2}$ \\
\hline 6 & $\begin{array}{l}\text { I think that mountains, rivers, and rocks posses divinity that is } \\
\text { connected to God. }\end{array}$ & .68 & .19 & -.32 & -.06 & .46 \\
\hline 27 & $\begin{array}{l}\text { I think that my body would be clean after I soak myself into clean } \\
\text { water. }\end{array}$ & .63 & -.12 & .10 & -.06 & .40 \\
\hline 26 & $\begin{array}{l}\text { I think that exposing myself in a waterfall at the river in the } \\
\text { mountain is a powerful and effective way of acquiring purity } \\
\text { mentally. }\end{array}$ & .58 & -.07 & .11 & -.06 & .34 \\
\hline 28 & I think that keeping my body clean is effective for calming down. & .53 & -.01 & .11 & .01 & .28 \\
\hline 34 & $\begin{array}{l}\text { I think that my family experience something terrible if I never vis it } \\
\text { my ancestors' graves. }\end{array}$ & .52 & .20 & .14 & -.05 & .27 \\
\hline 7 & $\begin{array}{l}\text { I think that nature will show its fury if human beings continue } \\
\text { environmental destruction. }\end{array}$ & .48 & .22 & -.05 & .07 & .23 \\
\hline 5 & I strongly feel in awe of the greatness of nature. & .47 & .01 & -.16 & .09 & .22 \\
\hline 46 & I think that my mouth gets corrupted by telling a lie. & .46 & -.01 & .19 & .03 & .21 \\
\hline 47 & $\begin{array}{l}\text { I feel like getting a fresh start and revitalized mentally and } \\
\text { physically when a new year has come. }\end{array}$ & .44 & .14 & .04 & .01 & .19 \\
\hline 32 & $\begin{array}{l}\text { I think that I will be cursed if I litter inside the grounds of a temple } \\
\text { and shrine. }\end{array}$ & .15 & .77 & -.03 & .01 & .59 \\
\hline 31 & I think that I will be cursed if I steal the offerings placed at graves. & .1 & .73 & -.03 & -.02 & .53 \\
\hline 19 & $\begin{array}{l}\text { I feel uncomfortable putting amulets and talismans from last year } \\
\text { in the trash cans. }\end{array}$ & -.04 & .62 & -.07 & .02 & .38 \\
\hline 35 & $\begin{array}{l}\text { I never want to live in an apartment where someone killed } \\
\text { him/herself. }\end{array}$ & -.13 & .55 & .13 & .12 & .30 \\
\hline 1 & $\begin{array}{l}\text { I think that it is inexpiable to make religious institutions (such as } \\
\text { a shrine) dirty. }\end{array}$ & .19 & .47 & .04 & -.01 & .22 \\
\hline 20 & I feel cordiality from the amulets given by someone. & .14 & .43 & -.04 & -.06 & .18 \\
\hline 22 & $\begin{array}{l}\text { I think that inappropriate sexual behavior makes my soul dirty } \\
\text { and leads to an unhappy life. }\end{array}$ & .05 & -.09 & .73 & .01 & .53 \\
\hline 23 & $\begin{array}{l}\text { I think that vicious thoughts make my soul dirty and leads to an } \\
\text { unhappy life. }\end{array}$ & .24 & -.13 & .67 & .02 & .45 \\
\hline 21 & I think that sex drive makes my soul dirty. & -.05 & -.11 & .6 & -.01 & .36 \\
\hline 30 & I think that cheating and adultery make my body and soul dirty. & -.21 & .38 & .53 & -.04 & .28 \\
\hline 43 & $\begin{array}{l}\text { It is dirty to have sexual relationship with a biologically close } \\
\text { individual. }\end{array}$ & -.12 & .19 & .47 & .04 & .22 \\
\hline 29 & $\begin{array}{l}\text { I think that going on a compensated date makes my body and } \\
\text { soul dirty. }\end{array}$ & -.18 & .33 & .47 & -.03 & .22 \\
\hline 37 & It is inexpiable to walk on the street naked. & -.03 & .24 & .43 & -.15 & .18 \\
\hline 13 & $\begin{array}{l}\text { I feel uncomfortable sharing a large platter or a hotpot with other } \\
\text { people. }\end{array}$ & .01 & -.18 & -.04 & .69 & .48 \\
\hline 2 & $\begin{array}{l}\text { I don't want to use the mug that someone else uses regularly, } \\
\text { even after it is sanitized. }\end{array}$ & -.03 & -.05 & .10 & .56 & .31 \\
\hline 12 & $\begin{array}{l}\text { Although some people can eat the food that is dropped on the } \\
\text { ground, I can never do it. }\end{array}$ & -.06 & .14 & -.06 & .55 & .30 \\
\hline 10 & $\begin{array}{l}\text { I want to go elsewhere if someone next to me on the train seems } \\
\text { to have a cold and coughs terribly. }\end{array}$ & -.19 & .25 & .01 & .46 & .21 \\
\hline 11 & I feel uncomfortable if I do not wash my hands before meals. & .14 & .15 & -.05 & .44 & .19 \\
\hline \multicolumn{7}{|c|}{ Correlation matrix among rotated factors } \\
\hline & & \multirow[t]{4}{*}{1.00} & .56 & .49 & .29 & \\
\hline & & & 1.00 & .46 & .11 & \\
\hline & & & & 1.00 & .26 & \\
\hline & & & & & 1.00 & \\
\hline
\end{tabular}

Note. F1 = Mental Purity ; F2 = Respect for Religion; F3 =Bodily Purity; F4 =Pathogen Avoidance. 
The first factor indicating mental purity was named 'Mental Purity', and was represented by nine items. The second, named 'Respect for Religion', was relevant to religious and deviant behaviour at religious facilities. Six items were strongly associated with the second factor. The third factor, represented by seven items, involved bodily matters and sexual behaviour, and it was named 'Bodily Purity'. Finally, the fourth factor, represented by five items, was found to be relevant to pollution and the lack of cleanliness as well as concerning illness. We named this fourth factor 'Pathogen Avoidance'. Internal consistency was sufficient for all factors (Cronbach's alpha $=0.814,0.808,0.781,0.661)$.

Through a series of exploratory factor analyses, we found three factors for the Animism Scale, which were suggested as the original factor structures. We performed an exploratory factor analysis for the DS-R-J Scale. The analysis resulted in three factors, but the composition of the items was different from the results derived by Iwasa et al. (2018). According to the factor structure obtained in our factor analysis, we employed a different set of three subscales from the original structure. Those three subscales were named 'Dead body', 'Corruption', and 'Avoidance of uncleanness' (available online at https://osf.io/keuwd/?view_only=8a2c8a7280a04e149e8e3966a0f9820d). We calculated the means of the responses to the items belonging to each subscale for the DS-R-J and Animism Scale. Regarding the MFQ, the responses to the items for each moral foundation were summed up. The correlations between the subscales are presented in Table 2. 
Table 2.

POPA correlations with convergent and discriminant measures $(N=411)$.

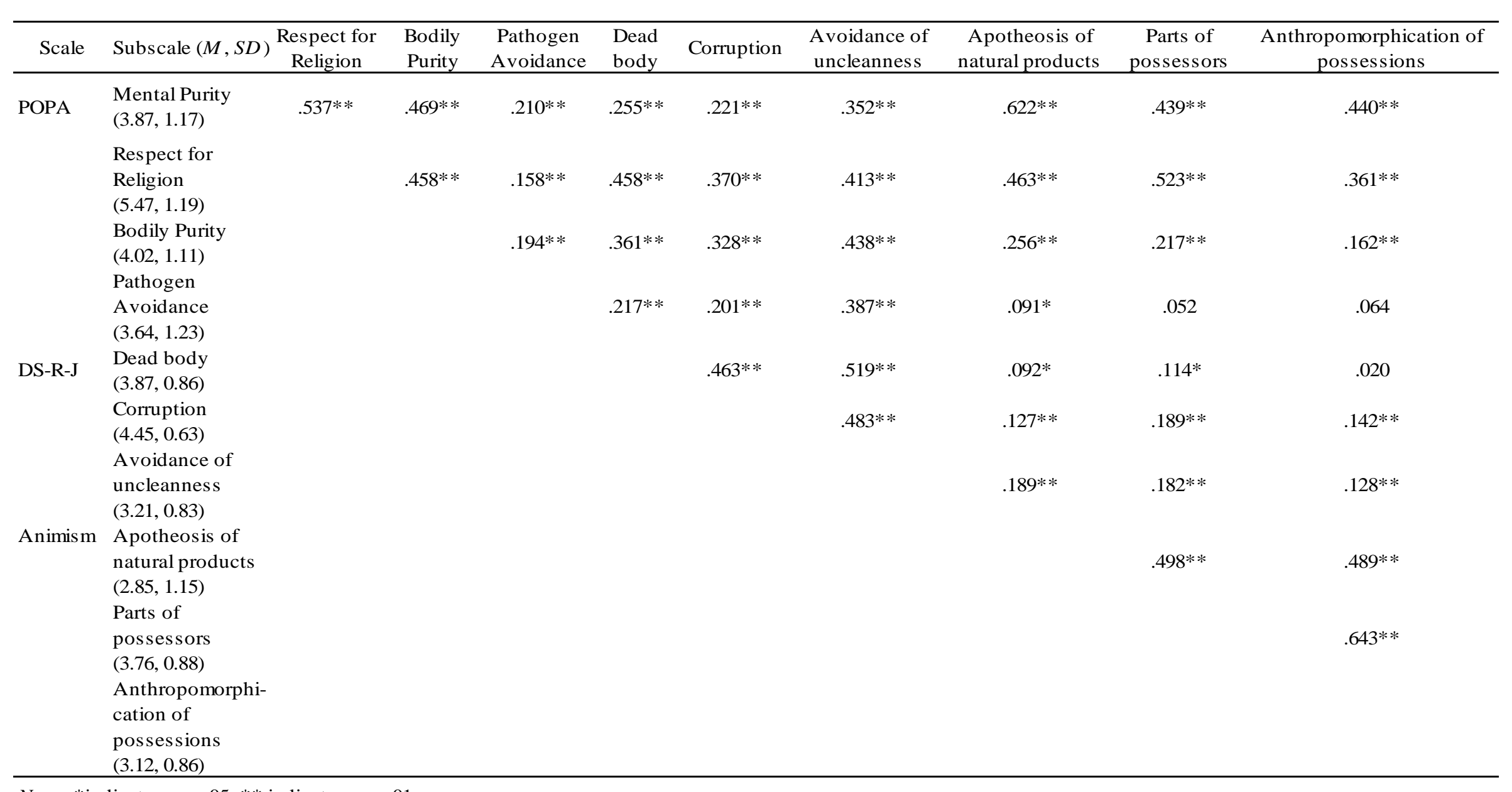


As expected, the subscales of POPA are weakly and moderately correlated to all the subscales-of the Disgust Scale (ranging from $r=0.201$ to 0.458 ). They are also weakly and moderately correlated to the subscales of the Animism Scale after the items that were similar to those in POPA (ranging from $r=0.052$ to 0.622 ) were eliminated. The 'Pathogen Avoidance' in the POPA was weakly correlated to both the Disgust and the Animism Scales, which makes this factor different from the others.

\section{Discussion}

We developed and validated the POPA. Japanese' purity orientation, which plays an important role in their value system, should be related the most to and reflected in the 'Mental Purity' subscale of the POPA because the 'Mental Purity' subscale represents one's tendency to actively pursue values in something pure. Because purity orientation among Japanese implies worship, that orientation should theoretically involve the 'Respect for Religion' subscale, as well. The 'Respect for Religion' subscale was found to include both items of a positive aspect and negative aspect: the attitudes towards being engaged in religious rituals to mourn the deceased and the sense of avoiding the pollution of the sacred. Accordingly, the 'Respect for Religion' subscale seems to involve both Japanese' purity orientation and pollution avoidance, which is not just about religious worship. Because the ideas underlying the 'Bodily Purity' and 'Pathogen Avoidance' are about being polluted in a physical sense, those subscales should be related to the pollution avoidance aspect of Japanese' purity orientation. The 'Pathogen Avoidance' subscale involves one's health in a practical sense and represents a sense of avoiding dirty and unhygienic conditions, unlike the 'Mental Purity' subscale. The 'Pathogen Avoidance' subscale represents passively avoiding pollution in a body-related term, so that this subscale features a slight difference from the other subscales that all involve religious and psychological factors to a greater or lesser 
degree. The 'Bodily Purity' subscale of the POPA tended to show a relatively high correlation to each of the subscales of the DS-R-J Scale. Pollution avoidance is basically an attitude against something dirty, its relationship with the reaction to disgust elicitors (which is measured by the DS-R-J Scale) demonstrates the validity of POPA. Further, all the POPA subscales, including 'Bodily Purity', are not highly correlated with the DS-R-J Scale because pollution avoidance is the feeling to seek psychological cleanliness, which is more than just physical hygiene. This correlation indicates that pollution avoidance is a different feeling from disgust and an independent psychological phenomenon of disgust, which demonstrates the validity of pollution avoidance as a concept and of the scale to measure the concept.

The DS-R-J features the items relevant to physical body, while the POPA was found to have multiple subscales that involves psychological purity and physical purity. The subscale categorization of the POPA is reasonable because the correlation between the 'Bodily Purity' subscale (i.e., physical purity) of the POPA and the DS-R-J was higher than that between the 'Mental Purity' subscale (i.e., psychological purity) and the DS-R-J. Japanese people's belief in Buddhism can explain why the correlation between the correlation between the 'Respect for Religion" of the POPA and the 'Dead Body' subscale of the DS-R-J was relatively high. In Buddhism, pollution is believed to be removed by properly mourning for the deceased. Thus, individuals who strongly feel disgust towards the ideas of death and pollution should be more likely to depend on Buddhist mourning rituals. The correlation between the POPA and the Animism Scales suggests that Japanese people's orientation to purity is associated with awe towards the invisible. This orientation involves not just the cleanliness of water and hygiene in a physical sense, but also the feeling and respectful attitudes towards something spiritual. This orientation may arise from Japanese people's respect for the figure like God. 
However, unlike Western cultures, the feeling of divinity is not always connected to God because monotheism is not familiar to the Japanese. For the Japanese, the feeling of divinity would be associated with polytheistic and animistic emotions like the naive respect for nature. Because of that attitudes, the 'Mental Purity' subscale of the POPA had exclusively a strong correlation with the 'Apotheosis of natural products' subscale of the animism scale. Also, the idea that inanimate objects can possess their spirits involved in the 'Mental Purity' subscale of the POPA can be interpreted as what the 'Anthropomorphication of possessions' subscale of the Animism scale represents. The belief that there are sprits and gods in the nature included in the 'Respect for Religion' subscale of the POPA can cause its correlation with the 'Apotheosis of natural products' subscale of the animism scale. Further, Japanese people often bring the objects they possessed for a long time and felt fond of to Buddhist temples and Shinto shrines, where those things undergo some religious rituals and will be properly discarded. That kind of Japanese people's behaviour can explain the relatively strong correlation between the 'Respect for Religion' of the POPA and the 'Parts of possessors' subscale of the Animism scale.

We examined whether nature worship was associated with familiarity with supernatural phenomena in Study 2. Considering that one's tendency towards Purity Orientation-Pollution Avoidance is considered to be related to one's pathogen avoidance from an evolutionary perspective, the items in the Pathogen Avoidance subscale were included in POPA. Although this subscale was found to be different from the other subscales in terms of the correlational patterns, it can be part of the moral foundation towards the pure, because uncleanness is often considered immoral (Zhong \& Liljenquist, 2006). 


\section{Study 2}

Study 2 is an effort (1) to explore the relationship between one's purity orientation and familiarity with supernatural phenomena, (2) to investigate the correlation of the purity items in the MFQ (Graham, Haidt, \& Nosek, 2009) and (3) to test the test-retest reliability of the POPA. No particular religion is prevalent in Japan, and most of the Japanese consider religion as something that is associated with superstitious beliefs. As a result, the Japanese population in general is not likely to perceive themselves believing in specific religious beliefs. However, like many people across the world, several Japanese too experience purity and awe by being in proximity with nature, e.g., watching big old trees or wandering and trailing in the woods and mountains. This feeling of awe is not scientific for the Japanese and is considered a wonder, but the feeling of awe has an aspect of reality for the Japanese. Thus, we attempted to find additional validity, investigating the relationship between POPA and Attitudes towards Paranormal Phenomena Scale (APPle), and the relationship between the Mental Purity subscale of POPA and the Purity subscale of the MFQ. Furthermore, the test-retest reliability of the POPA was tested.

\section{Method}

\section{Participants}

The participants included 199 Japanese undergraduate students enrolled in introductory psychology classes at a major Japanese private university, of whom 167 were males. They were recruited in the classes that included part of students who participated in Study 1 . Study 2 was conducted after two to three weeks after Study 1 . They agreed to participate in this study for extra credit or credit towards a course research requirement. There was no financial incentive provided to the participants. The survey was delivered online with Google Forms. Ethical review and approval by the ethics committee of 
Toyo University were obtained before conducting this study (P18033). The mean age of the participants was $19.70(S D=0.97)$. The procedure was the same as in Study 1 .

\section{Measures}

\section{Attitudes towards Paranormal Phenomena Scale short version}

According to Koshiro, Sakata and Kawakami (2008), paranormal phenomena are defined as sensations whose existence and effects have not been demonstrated, but are believed among people. Koshiro and collaborators developed a scale to measure Japanese people's attitudes towards such phenomena. The original version has 55 items and six subscales, but later, the authors made it shorter (Sakata, Kawakami, \& Koshiro, 2012). This short version has 30 items with six subscales. Its reliability and validity were found to be sufficient. It has been widely used in previous research conducted in Japan (e.g., Kawakami, 2020). Some sample items include 'Psychic power is interesting', 'I am fearful of UFOs' and 'I have seen a ghost'.

\section{Moral Foundations Questionnaire}

Based on the MFT, Haidt and his colleagues developed the MFQ. It is widely used to measure one's concern for each of the five moral foundations (Graham, Haidt, \& Nosek, 2009). We used the 30-item (longer) version of the Japanese MFQ that was back-translated and approved by the authors of the original MFQ (available at www.moralfoundations.org and in Kanai, 2013). The Japanese version of the MFQ was reported to have five factors as the MFT and the original MFQ predicted (Takamatsu \& Takai, 2017) and has been used in other research on morality among the Japanese people (e.g., Murayama \& Miura, 2019).

\section{Results and Discussion}

The test-retest reliability scores of the four subscales of the POPA were $r=0.745$, $0.734,0.699$ and 0.744 , respectively. We then calculated the means of the responses to 
the items belonging to each subscale for the APPle. Regarding the MFQ, the responses to the items for each moral foundation were summed up. The correlations between the subscales are presented in Table 3. 
Table 3

POPA correlations with convergent and discriminant measures $(N=199)$.

\begin{tabular}{|c|c|c|c|c|c|c|c|c|c|c|}
\hline Scale & Subscale $(M, S D)$ & $\begin{array}{l}\text { Respect for } \\
\text { Religion }\end{array}$ & $\begin{array}{l}\text { Bodily } \\
\text { Purity }\end{array}$ & $\begin{array}{l}\text { Pathogen } \\
\text { Avoidance }\end{array}$ & $\begin{array}{l}\text { Belief in } \\
\text { spirituality }\end{array}$ & $\begin{array}{l}\text { Preference for } \\
\text { fortune telling } \\
\text { and magic }\end{array}$ & Skepticism & $\begin{array}{l}\text { Enjoyment as } \\
\text { entertainment }\end{array}$ & Fear & $\begin{array}{l}\text { Supernatural } \\
\text { experience }\end{array}$ \\
\hline \multirow[t]{4}{*}{ POPA } & $\begin{array}{l}\text { Mental Purity } \\
(4.08,1.16)\end{array}$ & $.537 * *$ & $.433 * *$ & $.230 * *$ & $.590 * *$ & $.399 * *$ & $-.248 * *$ & .0601 & $.402 * *$ & $208 * *$ \\
\hline & $\begin{array}{l}\text { Respect for } \\
\text { Religion }(5.37,1.20)\end{array}$ & & $.413 * *$ & .135 & $.510^{* *}$ & $.303 * *$ & $-.291 * *$ & -.046 & $.219 * *$ & .036 \\
\hline & Bodily Purity $(4.15,1.09)$ & & & $.164^{*}$ & $.182 *$ & $.194 * *$ & -.0663 & $.151 *$ & $.192 * *$ & .113 \\
\hline & $\begin{array}{l}\text { Pathogen Avoidance } \\
(3.60,1.23)\end{array}$ & & & & .037 & .126 & .102 & .030 & .0588 & .063 \\
\hline \multirow[t]{6}{*}{ APPle } & $\begin{array}{l}\text { Belief in spirituality } \\
(2.96,1.07)\end{array}$ & & & & & $.532 * *$ & $-.358 * *$ & .069 & $.474 * *$ & $.231 * *$ \\
\hline & $\begin{array}{l}\text { Preference for } \\
\text { fortune telling } \\
\text { and magic } \\
(2.66,0.95)\end{array}$ & & & & & & $-.305 * *$ & $.185 * *$ & $.419 * *$ & $.323 * *$ \\
\hline & Skepticism $(3.38,0.94)$ & & & & & & & $.172 *$ & $-.183 * *$ & $-.233 * *$ \\
\hline & $\begin{array}{l}\text { Enjoyment as } \\
\text { entertainment } \\
(3.18,0.97)\end{array}$ & & & & & & & & .094 & $.155^{*}$ \\
\hline & Fear $(2.13,0.88)$ & & & & & & & & & $.344 * *$ \\
\hline & $\begin{array}{l}\text { Supernatural } \\
\text { experience } \\
(1.42,0.64)\end{array}$ & & & & & & & & & \\
\hline \multirow[t]{5}{*}{ MFQ } & Care $(4.07,0.79)$ & & & & & & & & & \\
\hline & Fairness $(3.88,0.69)$ & & & & & & & & & \\
\hline & Ingroup $(3.34,0.76)$ & & & & & & & & & \\
\hline & Authority $(3.36,0.73)$ & & & & & & & & & \\
\hline & Purity $(3.56,0.72)$ & & & & & & & & & \\
\hline
\end{tabular}




\begin{tabular}{|c|c|c|c|c|c|c|}
\hline Scale & Subscale & Care & Fairness & Ingroup & Authority & Purity \\
\hline \multirow[t]{4}{*}{ POPA } & Mental Purity & $.308 * *$ & $.249 * *$ & $.374 * *$ & $.289 * *$ & $.394 * *$ \\
\hline & $\begin{array}{l}\text { Respect for } \\
\text { Religion }\end{array}$ & $.430 * *$ & $.388 * *$ & $.299 * *$ & $.378 * *$ & $.455^{* *}$ \\
\hline & Bodily Purity & $.427 * *$ & $.307 * *$ & $.353 * *$ & $.403 * *$ & $.497 * *$ \\
\hline & Pathogen Avoidance & .083 & .095 & -.024 & .055 & .106 \\
\hline \multirow[t]{6}{*}{ APPle } & Belief in spirituality & .123 & $.193 * *$ & $.207 * *$ & $.225^{* *}$ & $.347 * *$ \\
\hline & $\begin{array}{l}\text { Preference for } \\
\text { fortune telling } \\
\text { and magic }\end{array}$ & .113 & $.153^{*}$ & $.238^{* *}$ & $.158^{*}$ & $.237 * *$ \\
\hline & Skepticism & -.0586 & .055 & $-.143^{*}$ & .0002 & -.104 \\
\hline & $\begin{array}{l}\text { Enjoyment as } \\
\text { entertainment }\end{array}$ & $.169^{*}$ & $.180^{*}$ & $.171 *$ & $.190 * *$ & .139 \\
\hline & Fear & .026 & -.022 & $.200 * *$ & .083 & $.171^{*}$ \\
\hline & $\begin{array}{l}\text { Supernatural } \\
\text { experience }\end{array}$ & -.002 & -.051 & .116 & .125 & .098 \\
\hline \multirow[t]{4}{*}{ MFQ } & Care & & $.634 * *$ & $.534 * *$ & $.374 * *$ & $.566^{* *}$ \\
\hline & Fairness & & & $.386^{* *}$ & $.412 * *$ & $.492 * *$ \\
\hline & Ingroup & & & & $.506^{* *}$ & $.498 * *$ \\
\hline & Authority & & & & & $.515^{* *}$ \\
\hline
\end{tabular}


Among the subscales of the APPle, the 'Belief in spirituality' refers to one's tendency to actively believe in supernatural phenomena, and the 'Preference for fortune telling and magic' is one's positive attitudes towards the information about fortune telling and the like in mass media and pop culture. These two subscales tap into the core idea of attitudes towards paranormal phenomena. We found a positive correlation between 'belief in spirituality' of the APPle and 'Mental Purity' of the POPA, $r=$ 0.590, which suggests that the psychological aspects of the purity orientation are associated with the familiarity one feels with invisible existence. This correlation was consistent with our expectation and demonstrated the construct validity of the POPA. Similarly, it was reasonable that a moderate positive correlation between the 'Preference for fortune telling and magic' of the APPle and the 'Mental Purity' of the POPA, $r=0.399$, was found, given that fortune telling is a practice that embodies customs and traditional religious culture in Japan (e.g., a fortune slip in a Shinto shrine). Compared to the 'Mental Purity' subscale, the 'Pathogen Avoidance' was not significantly correlated to the two subscales of the APPle mentioned above, probably because one's orientation toward a dirty body, sexual issues and pathogen-free cleanliness is different from a preference for supernatural phenomena. Therefore, the different correlations between each of the POPA subscales and the other scales show the validity of the POPA as an integrated concept with multiple subscales.

Conversely, 'Mental Purity' also reflects one's tendency to avoid pollution. Pollution itself is often something one subjectively imagines and is one's feeling that accuses something demonic for mysterious phenomena and natural disasters. People often perceive a supernaturally bad sign from a negative event and fear that something bad would happen, which is part of the purity orientation. That notion of purity orientation can make it reasonable that the positive correlation between the 'Fear' 
subscale of the APPle and the 'Mental Purity' of the POPA was observed, $r=0.402$, to validate the POPA because purity orientation involves not only the enjoyment of supernatural phenomena but also the fear of them.

As for the relationship with the MFQ, the subscales of the POPA are positively correlated to almost all the moral foundations, but their correlations with the Purity foundation were the strongest. Because of the correlations, a series of post hoc multiple regression analyses were performed with the scores for the five moral foundations in the MFQ as the predictors and the scores for the four subscales of the POPA as the outcome variables. The results show that, except for 'Pathogen Avoidance' that had the weakest correlations with the other scales of the POPA, the scores of all the subscales of the POPA were most strongly predicted by the Purity score of the MFQ (Table 4). The findings from the multiple regression analyses demonstrated the relationships between the POPA subscales and the MFQ subscales. The items about harming objects and other people in the 'Respect for Religion' and 'Bodily Purity' reflect the Japanese strong idea that it is wrong to damage objects and other people, which may be shown in the significant associations between those subscales of the POPA and the Harm subscale of the MFQ. 
Table 4

Summary of Multiple Regression Analyses for Variables Predicting POPA Scores

\begin{tabular}{|c|c|c|c|c|}
\hline $\begin{array}{l}\text { Criterion } \\
\text { Variable }\end{array}$ & Predictor & $\beta$ & $t$ & $R^{2}$ \\
\hline \multirow{5}{*}{$\begin{array}{l}\text { Mental } \\
\text { Purity }\end{array}$} & MFQ Harm Score & 0.06 & 0.59 & $0.19 * *$ \\
\hline & $\begin{array}{l}\text { MFQ Fairness } \\
\text { Score }\end{array}$ & 0.01 & 0.14 & \\
\hline & MFQ Ingroup Score & 0.20 & $2.28^{*}$ & \\
\hline & $\begin{array}{l}\text { MFQ Authority } \\
\text { Score }\end{array}$ & 0.03 & 0.40 & \\
\hline & MFQ Purity Score & 0.23 & $2.63 * *$ & \\
\hline \multirow{5}{*}{$\begin{array}{l}\text { Respect for } \\
\text { Religion }\end{array}$} & MFQ Harm Score & 0.22 & $2.35^{*}$ & $0.28 * *$ \\
\hline & $\begin{array}{l}\text { MFQ Fairness } \\
\text { Score }\end{array}$ & 0.09 & 1.03 & \\
\hline & MFQ Ingroup Score & -0.07 & -0.86 & \\
\hline & $\begin{array}{l}\text { MFQ Authority } \\
\text { Score }\end{array}$ & 0.18 & $2.29 *$ & \\
\hline & MFQ Purity Score & 0.24 & $2.83 * *$ & \\
\hline \multirow{5}{*}{ Bodily Purity } & MFQ Harm Score & 0.22 & $2.46^{*}$ & $0.29 * *$ \\
\hline & $\begin{array}{l}\text { MFQ Fairness } \\
\text { Score }\end{array}$ & -0.06 & -0.68 & \\
\hline & MFQ Ingroup Score & 0.02 & 0.20 & \\
\hline & $\begin{array}{l}\text { MFQ Authority } \\
\text { Score }\end{array}$ & 0.18 & $2.32 *$ & \\
\hline & MFQ Purity Score & 0.29 & $3.46^{* *}$ & \\
\hline \multirow{5}{*}{$\begin{array}{l}\text { Pathogen } \\
\text { Avoidance }\end{array}$} & MFQ Harm Score & 0.08 & 0.74 & 0.03 \\
\hline & $\begin{array}{l}\text { MFQ Fairness } \\
\text { Score }\end{array}$ & 0.05 & 0.52 & \\
\hline & MFQ Ingroup Score & -0.15 & -1.63 & \\
\hline & $\begin{array}{l}\text { MFQ Authority } \\
\text { Score }\end{array}$ & 0.02 & 0.27 & \\
\hline & MFQ Purity Score & 0.09 & 0.96 & \\
\hline
\end{tabular}

Note. *indicates $p<.05 ; * *$ indicates $p<.01$.

Although purity/pollution involves the purity that religious offerings are believed to have, it is also represented in everyday meals and secular food. The idea that purity plays a crucial role in something ingested from a mouth are observed not only in 
Japan and in the West. For example, Jewish and Muslim people do not eat pork because pork is believed to be polluted. Vigilance against food can be, in an evolutionary term, connected to one's psychological tendency of avoiding pathogen infection in the area he/she resides in. The Purity subscale of the MFQ was not associated with the 'Pathogen Avoidance' of the POPA in this study, but the relationship between those two subscales should be observed. The inconsistency may come from the MFQ and represent cultural differences. Cross-cultural comparisons should be awaited in future to investigate how pathogen avoidance is pronounced in Japan.

The results showed that all subscales except for the 'Mental Purity' and 'Pathogen Avoidance' of the POPA were moderately correlated to the Purity subscale of the MFQ. This does not suggest that 'Mental Purity' and 'Pathogen Avoidance' are separate scales, but it mean that the Japanese version of the scale is equivalent to the Purity subscale of the MFQ. Since the Purity items in the MFQ are not suitable for Japanese people's attitudes and emotions involving religiosity and attitudes towards divine existence, the low correlation of the 'Mental Purity' and 'Pathogen Avoidance' of the POPA and the Purity subscale of the MFQ may have been observed. In summary, the validity and reliability of the POPA were demonstrated.

\section{General Discussion}

This work developed the Purity Orientation-Pollution Avoidance (POPA) scale and tested its validity and reliability. We included items related to the six factors related to the Japanese concept of purity (i.e., religiosity, death, nature worship, body, sexual issues and disgust of cleanliness and uncleanness), referring to the characteristics of Japanese culture. Our factor analysis revealed four components, all of which concerned

pollution. The 'Pathogen Avoidance' factor includes the items regarding not only sexual issues, such as incest, that are avoided evolutionally, but also misdeeds of one's body 
and sexual relationships and what is considered as a 'taboo' in society. The 'Mental Purity' factor involves infection avoidance, which is an important aspect of POPA for evolutionary purposes. The 'Respect for Religion' factor consists of items about (avoidance of) immoral behaviour in the Japanese religious institutions of temples and shrines. These items can be translated and used in the West when the expressions in the items are appropriately modified. For instance, the religious institutions mentioned in the original items would be changed into the church, and a 'bad karma' into inviting God's wrath or deviating from God's will.

We specifically focussed on the 'Mental Purity' factor. The pursuit of mental cleanliness is of late not limited to people in the East because of the latest trend in yoga and oriental meditation. This oriental meditation is widely believed to have an essential effect to purify one's spirit, which allows people to reform bad old customs, and accordingly lead a desirable life. In addition to the 'Mental Purity' factor, 'Respect for Religion' and 'Bodily Purity', involve something people cannot directly perceive or influence their behaviour. Meanwhile, the 'Pathogen Avoidance' factor is associated with more concrete and familiar concepts (e.g., germs, unsanitary). Regarding the sense of mentality, the 'Pathogen Avoidance' factor may be qualitatively different from the other factors, which can explain the different patterns in the correlation with the other factors. Additionally, we found that the 'Pathogen Avoidance' subscale of the POPA was not significantly correlated with any foundation of the MFQ. Purity foundations should theoretically include the idea of avoiding pathogens in terms of morality about cleanliness. Considering our findings, it is possible that the items of the MFQ fail to measure the aspect of pathogen avoidance, which suggests that there is still room for improvement. Men participated more than women in Studies 1 and 2. Women were found to score higher in the 'Pathogen Avoidance' subscale of the POPA than men, 
which may indicate the possibility that there are gender differences in how much the subscale have effects on other variables. This finding may be consistent with some previous research that showed sex differences in disgust sensitivity and the fear of contamination with women scoring higher than men (Arrindell, Mulkens, Kok, \& Vollenbroek, 1999; Haidt, McCauley, \& Rozin, 1993; Olatunji, Sawchuk, Arrindell, \& Lohr, 2005). More equal sample collection of men and women to investigate whether the present research is replicable is needed for future research.

The concept of one's purity orientation can be applied to research on various contexts, such as discrimination against outgroup members, (former) criminals, and the attitudes toward immigrants, radioactive contamination and political corruption. Future research can investigate the possibility that attitudes towards outgroups depend not only on Pathogen Avoidance in a physical sense but also on purity orientation in a psychological sense. What regulates the relationship between purity orientation and these factors will be a prospective direction to scrutinise. In addition, cross-cultural comparisons regarding purity orientation would be of interest for future research. A cross-cultural approach can evaluate possible relationships between purity orientation, self-construal and relational mobility, and can further identify social and ecological factors to intensify one's purity orientation. Overall, POPA is a promising tool to contribute to future research, not only in psychology but also in other academic areas, such as folklore and sociology. This work contributes to moral psychology to better understand the complicated mechanisms of purity, its function and its relationships with other concepts. 


\section{References}

Arrindell, W. A., Mulkens, S., Kok, J., \& Vollenbroek, J. (1999). Disgust sensitivity and the sex difference in fears to common indigenous animals. Behaviour Research and Therapy, 37, 273-280.

Baba, Y. (2000). Space classifications and ideas of "dirty" in Japan. Otsuma Women's University Faculty of Literature Departmental Bulletin, 32, 115-131.

Douglas, M. (2003). Purity and Danger: An Analysis of Concepts of Pollution and Taboo. Routledge.

Gelfand, M. J., \& Denison, E. E. (2020). Moving beyond the West vs. the rest: Understanding variation within Asian groups and its societal consequences. Proceedings of the National Academy of Sciences, 117(10), 5100-5102.

Graham, J., Haidt, J., \& Nosek, B. A. (2009). Liberals and conservatives rely on different sets of moral foundations. Journal of Personality and Social Psychology, 96, 1029. DOI: 10.1037/a0015141

Graham, J., Nosek, B. A., Haidt, J., Iyer, R., Koleva, S., \& Ditto, P. H. (2011). Mapping the Moral Domain. Journal of Personality and Social Psychology, 101, 366. DOI: $\underline{10.1037 / \mathrm{a} 0021847}$

Graham, J., \& Haidt, J. (2010). Beyond Beliefs: Religions Bind Individuals into Moral Communities. Personality and Social Psychology Review, 14, 140-150.

DOI: $10.1177 / 1088868309353415$

Graham, J., Haidt, J., Koleva, S., Motyl, M., Iyer, R., Wojcik, S. Pl., \& Ditto, P. H. (2013). Moral Foundations Theory: The Pragmatic Validity of Moral Pluralism. Advances in Experimental Social Psychology, 47, 55-130.

DOI:10.1016/B978-0-12-407236-7.00002-4 
Haidt, J. (2012). The Righteous Mind: Why Good People are Divided by Politics and Religion. Vintage.

Haidt, J., McCauley, C., \& Rozin, P. (1993). Individual Differences in Sensitivity to Disgust: A scale sampling seven domains of disgust elicitors. Personality and Individual Differences, 16, 701-713.

Ikeuchi, H. (2010). Animistic thinking in adults: The memorial service for dolls as a voluntary loss. Japanese Journal of Social Psychology, 25, 167-177. (In Japanese with English Abstract).

DOI: $\underline{\text { https://doi.org/10.14966/jssp.KJ00006203282 }}$

Ishikawa, Y. (2012). Syugendo as Transpersonal Psychotherapy: The Psychological Process of Ascetic Practices and Syugendo Therapy. Japanese Journal of Transpersonal Psychology/Psychiatry, 12, 49-72.

Ito, N. (2002). Discussion about impurity and boundaries. Nagoya University Studies in Language and Culture Departmental Bulletin, 24, 3-22.

Iurino, K. \& Saucier, G. (2018). Testing Measurement Invariance of the Moral Foundations Questionnaire Across 27 Countries. Assessment. DOI: $10.1177 / 1073191118817916$

Iwasa, K., Tanaka, T., \& Yamada, Y. (2018). Factor Structure, Reliability, and Validity of the Japanese Version of the Disgust Scale-Revised (DS-R-J). The Japanese Journal of Psychology, 89, 82-92.

DOI: https://doi.org/10.4992/jjpsy.89.16230

Kanai, R. (2013). Nou ni kizamareta moraru no kigen: Hito wa naze zen wo motomerunoka. [The origin of morality engraved in the brain: Why do people pursue goodness?] Iwanami Publisher. 
Kaur, R., \& Sasahara, K. (2016, December). Quantifying moral foundations from various topics on Twitter conversations. In 2016 IEEE International Conference on Big Data (Big Data) (pp. 2505-2512). IEEE.

Keltner, D. \& Haidt, J. (2003). Approaching Awe, a Moral, Spiritual, and Aesthetic Emotion. Cognition and Emotion, 17, 297-314.

DOI:10.1080/02699930302297

Koleva, S. P., Graham, J., Iyer, R., Ditto, P. H., \& Haidt, J. (2012). Tracing the threads: How five moral concerns (especially Purity) help explain culture war attitudes. Journal of Research in Personality, 46(2), 184-194.

DOI: https://doi.org/10.1016/j.jrp.2012.01.006

Koshiro, E., Sakata, H., \& Kawakami, M. (2008). Attitudes towards paranormal phenomena: Structural analysis and categorization of attitudes. Japanese Journal of Social Psychology, 23, 246-253.

DOI: $\underline{\text { https://doi.org/10.14966/jssp.KJ00004896220 }}$

Miyamoto, Y. (2008). On the Meaning "Religious Pollution" from a Perspective of Comparative Religion. Kansai University Departmental Bulletin: Department of Letters, 58, 61-80.

Murayama, A. \& Miura, A. (2019). Validation of the Japanese version of the moral foundation questionnaire: Investigating the relationship with ideologies. The Japanese Journal of Psychology, 90, 156-166.

DOI:10.4992/jjpsy.90.17234

Namihira, E. (2009). Kegare. [Impurity] Kodansha Publisher.

O, G. (2009). The Ideas of Soul of the Shinto-Buddhist Syncretism in Nara • Heian Periods. The bulletin of the Graduate School, Soka University, 31, 271-286. 
Olatunji, B. O., Sawchuk, C. N., Arrindell, W. A., \& Lohr, J. M. (2005). Disgust sensitivity as a mediator of the sex differences in contamination fears. Personality and Individual Differences, 38, 713-722.

Preston, J. L., \& Ritter, R. S. (2012). Cleanliness and Godliness: Mutual association between two kinds of personal purity. Journal of Experimental Social Psychology, 48(6), 1365-1368.

DOI: https://doi.org/10.1016/j.jesp.2012.05.015

Rozin, P., Lowery, L., Imada, S., \& Haidt, J. (1999). The CAD triad hypothesis: a mapping between three moral emotions (contempt, anger, disgust) and three moral codes (community, autonomy, divinity). Journal of Personality and Social Psychology, 76, 574.

DOI: $\underline{10.1037 / / 0022-3514.76 .4 .574}$

Sakata, H., Kawakami, M., \& Koshiro, E. (2012). Constructing attitudes towards paranormal phenomena scale (APPle) short edition (1): Attitudes towards Paranormal Phenomena (29) [Paper presentation]. 76th Conference of the Japanese Psychological Association.

Shiota, M. N., Keltner, D., \& Mossman, A. (2007). The nature of awe: Elicitors, appraisals, and effects on self-concept. Cognition and Emotion, 21, 944-963. DOI:10.1080/02699930600923668

Shweder, R., Much, N., Mahapatra, M., \& Park, L. (1997). Divinity and the "big three" explanations of suffering. Morality and Health, 119, 119-169.

Takamatsu, R. \& Takai, J. (2017). Validation of the Japanese version of moral expansiveness scale. Japanese Journal of Interpersonal and Social Psychology, 17, 93-102. DOI:info:doi/10.18910/67200 
Tanaka, T. (2004). Consumers' risk perceptions and risk behavior. Japan Institute of Life Insurance Journal, 149, 161-186.

Uehara, C. (2017). The relationships between bodily cleanliness, sensitivity, excitement, and psychological attitudes. [Paper presentation]. 25th Conference of Japan Society for Research on Emotions.

Usui. A. (1986). Various aspects of avoidance: Part 1. Hitotsubashi Journal of Social Sciences, 11, 21-37.

Van Leeuwen, F., Park, J. H., Koenig, B. L., \& Graham, J. (2012). Regional variation in pathogen prevalence predicts endorsement of group-focused moral concerns. Evolution and Human Behavior, 33(5), 429-437.

DOI: 10.1016/j.evolhumbehav.2011.12.005

Xu, J. (2013). Comparison of the view of life and death between Japanese and Chinese people. Osaka University Clinical Philosophy Departmental Bulletin, 15, 35-54.

Zhong, C. B., \& Liljenquist, K. (2006). Washing away your sins: Threatened morality and physical cleansing. Science, 313(5792), 1451-1452.

DOI: $10.1126 /$ science. 1130726 